\title{
Figurações do feminino em Agustina Bessa-Luís
}

Tatiana Alves Soares Caldas

CEFET / RJ

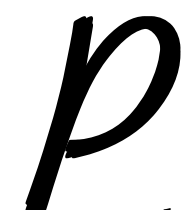

ensar a condição da mulher na sociedade patriarcal a partir da caracterização das personagens femininas no texto literário implica uma profunda reflexão acerca dos mecanismos de representação. Acrescente-se a isso uma apreensão do mundo a partir de um foco narrativo também feminino, e temos então uma crítica realizada pelo próprio objeto, numa situação em que aquele que se vê representado investiga - e questiona - a própria condição.

Agustina Bessa-Luís realiza em sua obra a reivindicação que normalmente caracteriza a ficção de autoria feminina: apresenta a mulher como temática recorrente, e as personagens femininas, muitas vezes rudes e provincianas, assumem um caráter universal e cósmico que lhes permite realizar um verdadeiro questionamento acerca do papel da mulher no mundo. Irreverentes, libertárias, transgressoras, cada uma dessas mulheres retrata um aspecto do feminino na sociedade. A trajetória e a caracterização de tais personagens refletem uma proposta de redimensionamento dos valores canonizados, e é desse redimensionamento que trata este estudo.

As mulheres da ficção agustiniana encarnam uma espécie de arquétipo feminino, uma essência da psique feminina, que pode ser vista tanto a partir de sua caracterização quanto em suas atitudes. Isabel Allegro de Magalhães, em seu conhecido estudo acerca do tempo feminino, destaca a supremacia de tais personagens, bem como associa essa superioridade ao caráter 
transgressor que as caracteriza: "Esse instinto de liberdade, nós o chamaremos, com Agustina, subversão. Em geral, são as mulheres que se revoltam, que contrariam as regras estabelecidas, que exercem a subversão."1

Mulheres que desprezam a vulgaridade e a mesmice, a Fisalina d'A mãe de um rio, a Josefina d'O mosteiro e a Eugénia de Eugénia e Silvina são, sobretudo, vanguardistas. Curiosamente, todas assumem atitudes viris e aparecem em situações tipicamente masculinas, subvertendo os estereótipos vigentes em sociedades patriarcais. Ao se colocarem no papel tradicionalmente atribuído ao homem - cavalgando, manuseando armas de fogo, escolhendo parceiros -, essas mulheres acabam por intimidar os homens ao seu redor. Curiosamente, os parceiros escolhidos parecem sofrer de uma espécie de misoginia - como é o caso de Belche, n'O mosteiro -, ou recebem uma caracterização andrógina, como o tenente que supostamente seria amante de Eugénia Viseu. Ao negar a passividade normalmente esperada da mulher, as personagens femininas invertem a situação, fragilizando o homem e expondo-lhes a fraqueza. O desejo de Josefina de ter o mesmo reconhecimento que os homens a leva a reproduzir o comportamento masculino, atitude condenada pela sociedade.

A recusa à submissão leva algumas dessas mulheres a inverter os papéis sociais, como a Eugénia de Eugénia e Silvina, que realiza um jogo de sedução com o amante, numa relação marcada pela ambiguidade e pela permuta de papeis sexuais.

Maria Rita Kehl, psicanalista e autora de diversos ensaios acerca do binômio masculino / feminino, analisa, em A mínima diferença, a tênue fronteira que separa esses campos. Acreditando que os gêneros sempre estiveram unidos no inconsciente, a autora revela o papel da cultura nessa separação, bem como suas consequências. Ao demonstrar o peso da cultura nas

${ }^{1}$ MAGALHÃES, 1989, p. 245. 
mentalidades, Kehl reflete acerca da individualização, que, em contexto massificado, implica diferença e exclusão. Segundo ela, a diversidade, ao invés de propiciar um enriquecedor diálogo, gera intolerância, uma vez que a sociedade massificada não aceita a diferença. Nesse tipo de sociedade, a manutenção do grupo é garantida pela exclusão daqueles que se afastam dos padrões impostos. E, significativamente, a ameaça reside naquele espaço em que a diferença é mínima, tornando-se necessária a marginalização do outro para que o eu permaneça em segurança. Desse modo, o conceito de identidade estabelecese pela negação da voz da alteridade. Ao refletir sobre essa ameaça, Kehl pensa o temor da sociedade diante de mulheres e épocas revolucionárias, mostrando o perigo, para o homem, de a mulher querer gozar dos mesmos direitos e privilégios.

Na dicotomia presente na questão do gênero, uma das marcas mais sensíveis está ligada aos espaços - público e privado - em que o sujeito atua. A ideologia patriarcal demarca o espaço público como masculino, condenando o feminino à esfera do doméstico, veiculando uma representação de papéis fixos. Essa ideologia, transmitida de modo subliminar, realiza um processo de dominação inconsciente, perpetuando valores e imagens introjetados ad infinitum. Cria-se, então, uma aura de imutabilidade em torno dessas representações que confinam a mulher, enquanto o homem recebe o papel social ligado ao poder è̀ aventura. Assim, os trabalhos ditos femininos envolvem basicamente atenção, disciplina e rotina, enquanto o homem tem a missão de decidir, planejar, construir. Além disso, o fato de as mulheres receberem salários inferiores aos dos homens, ainda que executem as mesmas tarefas, acaba por perpetuar esse processo de dominação. A falta de recursos refreia as tentativas de independência da mulher, sendo uma das críticas detectadas na obra de Agustina: 
Josefina não era a heroína abatida pela desgraça; tinha, porém, poucos conhecimentos e não dispunha de dinheiro contado. Esta é a grande algema da mulher que se vê sobrecarregada com a falta na sua virtude e a falta de credibilidade bancária, ao mesmo tempo. ${ }^{2}$

A falta de credibilidade bancária que vitima Josefina reflete a crítica à sociedade, que oprime a mulher através do poder econômico. Em um dos mais consagrados textos de teor feminista, Um teto todo seu, Virginia Woolf vincula a independência financeira à social. Dominada pelo poder econômico, a mulher fica à mercê daquele - pai ou marido - que a sustenta. Em Eugénia e Silvina, é graças ao dinheiro que Eugénia faz com que todos se curvem ao seu poder, num reflexo de tal estrutura.

Além de aceitar o comportamento de Eugénia, a sociedade assiste à subserviência do tenente, numa servidão que nem a patente nem o pomposo sobrenome conseguem evitar. Ao perceber o prestígio do dinheiro, Eugénia compra a própria liberdade, escapando ao inexorável destino feminino.

Pertencentes a uma sociedade repressora, muitas personagens veem na negação dos valores vigentes o protesto contra essa injustiça. Na contramão do comportamento esperado, deparamo-nos com mulheres que se envolvem com homens apenas pela perspectiva de transgressão, tomando para si o papel volúvel desempenhado por eles e subvertendo as relações de poder que legam a mulher à condição de objeto e nunca de sujeito - do desejo.

Uma vez que a mulher é percebida como o ser nãomasculino, sua identidade forma-se a partir de uma negação, em vez da afirmação de uma categoria distinta. Dessa forma, as noções vinculadas ao modelo ideal masculino assumem o

${ }^{2}$ BESSA-LUÍS, 1980, p. 82. 
estatuto de normalidade, sendo qualquer transgressão dessa ordem imediatamente relacionada à loucura. Nesse sentido, é significativo o fato de a literatura das épocas mais repressoras em relação à mulher ser repleta de loucas que vivem no sótão, imagem que retrata, literal e figurativamente, a exclusão. A temática da loucura não é inocente nem gratuita. Uma das formas de silenciamento consiste precisamente em situar o indivíduo fora dos limites da sociedade, banindo-o. Assim, os parâmetros que atribuem normalidade ou loucura à mulher baseiam-se na sua adequação ou não ao modelo desejado. Maria, $\mathrm{n}^{\prime} A$ sibila, vale-se de seus momentos de loucura para escapar das regras da sociedade. Paradoxalmente, o louco, excluído da sociedade dita normal, paira em uma espécie de limbo, libertandose do código social. A sociedade amedronta-se diante desse ser alheio às normas de conduta, e muitas personagens de Agustina encarnam esse papel, contestando a ordem vigente.

Essa contestação é percebida também no riso, atitude frequente em algumas personagens, ressaltando sua irreverência diante do status quo. Quando o acesso de riso - aparentemente sem motivo - parte de alguém marcado pela austeridade, o gesto ainda se torna mais eloquente. Estina, n'A sibila, é uma mulher habitualmente séria e comedida. Mãe de uma doente mental e casada com um homem cruel, ela contrabalança sua infelicidade com os ataques de riso convulsivo, negando a amargura normalmente verificada em alguém que vivenciasse um cotidiano tão despojado de atrativos. Ainda que se trate de um riso de fundo nervoso, o constrangimento causado por suas gargalhadas histéricas destrói, de algum modo, o aparente equilíbrio da realidade hipócrita ao seu redor.

A atitude de recusa da realidade opressora efetua-se a partir da negação de valores sacralizados, como a educação, o casamento, e tantos outros mecanismos de repressão à mulher. O matrimônio é rejeitado pela maioria das personagens, e aquelas que não o fazem são frequentemente apresentadas 
como vítimas de homens tiranos ou inconsequentes. A educação é criticada em virtude do conformismo que acarreta, e, curiosamente, as reflexões partem de mulheres primitivas, que, apesar de sua rusticidade, percebem a opressão e defendem a liberdade de pensamento. Isabel Allegro, ao pensar essa aversão ao casamento, tão presente nos romances da autora, identifica uma espécie de autossuficiência nas mulheres da ficção de Agustina, uma grandeza típica daquelas que ela classifica como mulheres de raça:

Em Agustina as "mulheres fortes" tendem a uma vida em que se assumem a si mesmas como "seres completos", seres que não precisam de uma outra "metade" para serem, mas que por isso mesmo são no geral também mulheres sós, que escolhem não casar [...]. Nos romances de Agustina a solidão parece ser uma forma de estar no mundo que caracteriza as mulheres "de raça": aquelas em quem vive uma grandeza misteriosa e rara. ${ }^{3}$

A opção de não se casar envolve uma conscientização acerca da condição feminina. O casamento, em sociedades que oprimem a mulher, normalmente constitui um dos mecanismos em que tal dominação se apoia. $\mathrm{N}^{\prime} A$ sibila, Germa reflete criticamente sobre as bases do casamento tradicional, considerando-o mera transação financeira, vantajosa sobretudo para a família da moça que é comercializada. Em Eugénia e Silvina, o casamento da bastarda Eugénia é analisado de forma irônica pela narradora, que comenta a adequação do ar de defunta da noiva à cerimônia que ali se realizava.

Ao apresentar o casamento tradicional como uma quase morte em vida, a narradora reflete um aspecto marcante da obra de Bessa-Luís, que é a recorrente abordagem da problemática

${ }^{3}$ MAGALHÃES, 1989, p. 251. 
feminina. Essa voz, calada por um longo tempo, afirma-se como sujeito de seu discurso, um sujeito que tematiza o próprio desejo e é autorreferencializado. Trata-se, agora, do feminino falado a partir das entranhas, que se assume como sujeito e nega a condição de objeto a que fora relegado. É justamente a recusa à posição de objeto o que leva muitas dessas mulheres a ver no amor uma espécie de traição. O distanciamento em relação aos homens funciona como uma defesa para tais mulheres que, autossuficientes, não desejam renunciar a essa independência.

Entregar-se ao amor significa aceitar todo o caminho que a sociedade projeta para a mulher. O sonho romântico de encontrar o príncipe encantado para, a seu lado, viver feliz para sempre, funciona para elas como respaldo da ideologia patriarcal. Desse modo, a mulher vê-se obrigada a renunciar a esse sonho que lhe foi incutido desde os contos-de-fadas da infância, na tentativa de conduzir a própria vida. Talvez isso explique o fato de o amor ser uma fatalidade para as mulheres agustinianas. O envolvimento com o homem é visto como algo que aniquila a mulher. Trata-se de personagens que encontram sua forma de equilíbrio na solidão. $\mathrm{N}^{\prime} A$ sibila, por exemplo, a linhagem de mulheres é referida como o verdadeiro esteio da casa, havendo mesmo uma repulsa, por parte dessas mulheres, pela frivolidade masculina. $\mathrm{O}$ desprezo pelos homens, bem como a imitação de seu comportamento, traduz um aspecto importante da obra de Bessa-Luís: a análise das relações humanas. A apreensão do mundo dá-se, na obra da autora, por meio de digressões e aforismos que, na maioria das vezes, tematizam as relações entre homens e mulheres. A própria narradora frequentemente mostra-se cética, analisando com amarga ironia os relacionamentos amorosos, como se a harmonia entre masculino e feminino fosse uma utopia. Suas palavras trazem por vezes uma reflexão acerca dos papéis sexuais e da inserção da mulher no mercado de trabalho. A mulher poderosa, que 
intimida o homem, constitui um desafio que pode levá-lo à perdição. Os personagens masculinos que se envolvem com mulheres fortes apresentam uma destituição de sua virilidade, como já apontamos anteriormente. $\mathrm{N}^{\prime} \mathrm{O}$ mosteiro, o caráter andrógino do personagem Belche é vislumbrado na descrição do seu quarto, cujos móveis amputados e gangrenosos traduzem a impotência do dono. Josefina, mulher que ao mesmo tempo o fascina e amedronta, decide mudar a disposição dos móveis, numa transformação simbólica do interior de seu dono. Curiosamente, quando o quarto adquire virilidade ele não mais o reconhece, optando por outro quarto, pobre e defeituoso.

A constatação de suas fraquezas, bem como a rejeição que sofre por parte das tias, gera uma atitude misógina em Belche, cuja vida fora marcada pela presença de mulheres fortes. Ao retratar personagens masculinos que se amedrontam diante do poder feminino, Bessa-Luís prova serem as diferenças entre os gêneros causadas principalmente por fatores culturais.

Nessa denúncia, surgem diferentes feições do feminino, de mulheres fortes ou enigmáticas a outras reclusas e submissas, todas retratando algum aspecto da realidade. Em Eugénia e Silvina, até mesmo a figura quase caricatural e idiotizada da criada Albina é enfocada na reflexão acerca da posição da mulher no mundo, uma vez que critica mulheres que se comportam como mero reflexo das expectativas masculinas. Extremamente convenientes à primazia do homem, estereótipos como os da mulher-burra e da mulher-gueixa - aqui entendida como aquela cuja única função é agradar ao homem - preenchem necessidades do sujeito dominante, e é essa estrutura que o discurso feminino tenta repensar.

Em sua análise da condição feminina, a ficção de BessaLuís articula-se por vezes em torno de um dualismo um tanto tendencioso, que parece exacerbar, de modo maniqueísta, os defeitos dos homens e as virtudes femininas. Grosseiros, covardes, fúteis e egoístas, os homens são representados como 
aqueles que põem tudo a perder, enquanto as mulheres surgem como responsáveis e apegadas aos valores e raízes. N'A sibila, cuja imagem-chave é a do clã feminino, esse dualismo é flagrante. A temática das mulheres que defendem as terras e a propriedade com a própria vida enquanto os homens representam o infortúnio é retomada n'O mosteiro, traduzindo uma linha recorrente na obra da autora.

A distinção entre homens e mulheres perpassa a obra de Agustina, gerando uma dicotomia que apresenta o homem como um ser frívolo e pautado pelo tradicional, enquanto concede à mulher o dom do mistério e da subversão. Catherine Kong-Dumas, no instigante ensaio Mistério e realidade na obra de Agustina Bessa-Luís, analisa o estatuto mágico que circunda essas personagens femininas:

[...] As numerosas personagens que desempenham a função de "aias", guardiãs do fogo e do vinho são também guias para os mistérios.Mulheres embriagadas, grandiosas, lembram as Fúrias gregas. [...] As mulheres Rodom são arrastadas por um vento de subversão contagiosa. [...] Esse ímpeto subversivo pode chamar-se também cólera, desordem ou malícia, e até humor, porque ultrapassa uma visão tradicional da sociedade, a que podemos chamar realidade superficial, para que seja revelado o mistério. ${ }^{4}$

A aura mítica referida por Kong-Dumas constitui outra vertente dos romances de Agustina, fazendo das mulheres verdadeiras iniciadas em mistérios que compreendem intuitivamente. A harmonia e a integração com o Cosmos realizadas por essas mulheres conferem um tom panteísta à obra da autora.

Há, ainda, a imagem de espaços femininos considerados sagrados e relacionados à água. Em Eugénia e Silvina tem-se a

${ }^{4}$ KONG-DUMAS, 1982, p. 32. 
poça das feiticeiras, espaço anteriormente habitado pelas Mestras de Ranados, resquício das sacerdotisas celtas. N'A mãe de um rio, talvez o mais flagrante retrato da herança pagã, há a figura da Mãe, guardiã do tempo e da vida, em harmonia com a natureza.

O caráter mágico e sagrado de que se reveste a Mãe do rio evidencia uma mística feminina que se entrevê em tais narrativas. Essas mulheres, que por vezes se comportam como iniciadas, são pessoas simples e até mesmo ignorantes, sendo essa intuição uma espécie de dom.

Quina é uma das personagens que se singularizam em virtude de seu questionamento acerca da condição feminina. Apegada ao pai e vendo o sofrimento da mãe e da irmã nas mãos dos respectivos maridos, Quina decide jamais se casar. Ao perceber o caráter sexista do poder, assume atitudes cada vez mais próximas às dos homens, com o objetivo de se fazer respeitar por eles. No seu íntimo, porém, é dotada da veia mística que caracteriza as mulheres agustinianas. Dona de uma profunda perspicácia, ela desenvolve, após um longo período de doença, um conhecimento da natureza humana que lhe dá a fama de pitonisa.

O contato com o transcendente dá a essas mulheres uma aura mística. Como sacerdotisas, realizam experiências que as fazem ultrapassar os limites humanos. As mulheres de Agustina são geralmente misteriosas e radiantes, parecendo resgatar a conexão entre divino e humano. Significativamente, é a falha, e não a perfeição, o que as liga à divindade, numa destituição do paradigma cristão.

A negação das polaridades cristãs é vista, ainda, nas figuras luminosas dessas mulheres que encarnam sacerdotisas ou bacantes com igual desenvoltura, sem a necessidade de optar por um dos papéis. A valorização da mulher em BessaLuís dá-se justamente a partir da afirmação de características normalmente tidas como inferiores, utilizadas como respaldo 
da ideologia patriarcal. Desse modo, negar o cânone falocêntrico passa, forçosamente, pelo resgate dos valores até então subestimados.

A abordagem da condição feminina, já apontada aqui como um dos mais característicos traços da ficção agustiniana, parece por vezes constituir a própria matéria da enunciação, fazendo das reflexões acerca do lugar da mulher na sociedade o eixo central da obra.

Ao pensar a inserção da mulher na sociedade, a ficção agustiniana analisa a dificuldade daquela em se afirmar, dada a estrutura patriarcal que a oprime. Isabel Allegro, no já citado O tempo das mulheres, reflete sobre a precariedade da condição feminina, destacando o fato de o emparedamento - físico ou psicológico - que vitima as mulheres em sociedades falocêntricas aparecer de forma recorrente nos romances de Agustina, como que a reiterar o protesto realizado em sua obra. Entretanto, como a rebeldia constitui uma das marcas das personagens agustinianas, elas se mostram mais irreverentes quando a repressão é mais intensa. Em Eugénia e Silvina, nota-se a revolta de uma das protagonistas diante da austeridade do pai e dos valores que ele lhe tenta impor:

Silvina sentiu-se ludibriada. Trabalhava quinze anos para a casa, sem soldada, sujeita ao humor desabrido do "Joãozinho", que ora mimava, ora usava para com ela duma hostilidade indirecta ou uma grosseria franca. Na realidade, ele não se afastava muito da maneira patriarcal de criar as filhas, que era própria da antiga família beirã: severidade que arrefeça o calor do sangue e uma boa dose de sentido prático, porque uma mulher é sempre uma criada, protegida, mas não menos criada por isso..$^{5}$

${ }^{5}$ BESSA-LUÍS, 1990, p. 175. 
A crítica à criação patriarcal perpassa a obra, e fica patente na própria polissemia do termo criada, que se aplica tanto à forma de educar quanto à serviçal que atende à família. Pouco mais do que servas, as filhas dos patriarcas são esmagadas por uma estrutura que não lhes permite vislumbrar uma saída. Surgem, então, os subterfúgios, pequenas estratégias de sobrevivência da mulher em tais sociedades:

[Silvina] aprendera a hipocrisia como quem aprende piano; todas as teclas da dissimulação ela sabia tocar e tirar delas proveito. Era uma mulher de harém, dominadora debaixo dessa miséria de opinião que o pai dizia ser obediência filial. ${ }^{6}$

A hipocrisia de Silvina, habilidade que utiliza com a mesma desenvoltura com que as mocinhas de então executavam as lições de piano, retrata os artifícios femininos na tentativa de escapar ao seu destino pré-traçado. Como que para provar o seu destemor diante das situações, Silvina enfrenta deliberadamente o perigo, mostrando toda a sua ousadia:

Silvina era destemida e gostava às vezes de ir de noite aos coradouros colher a roupa esquecida, não porque fosse necessário, mas porque a treva fechada do pinhal do Deão a inspirava a ser ousada. Imaginava assaltos e a maneira de lhes responder; as palavras de ódio que proferiria, um ódio espirituoso que no perigo se arrebata em ditos grandiosos e de humor cruel. ${ }^{7}$

A atitude cruel e desafiadora demonstrada por ela traduz um aspecto encontrado em sociedades patriarcais: a face demoníaca da mulher. Ao pensar a dicotomia masculino /

\footnotetext{
${ }^{6}$ BESSA-LUÍS, 1990, p. 184.

7 BESSA-LUÍS, 1990, p. 181.
} 
feminino, Dulcinéia da Mata alude ao mito de Lilith, o qual, segundo ela, reflete o lado sombrio do feminino. A vingança de Lilith, decorrente da negação de seu poder, é representada sob a forma de bruxa, súcubo ou mãe devoradora. A faceta demoníaca do feminino irrompe do inconsciente, já que foi banida da esfera consciente:

[...] Este feminino demoníaco revela a repressão do feminino na sociedade dominada pelos valores patriarcais, que têm buscado o poder e o controle das forças da natureza. É sempre um grito de dor ao feminino ferido e ao sentimento de baixa autoestima. ${ }^{8}$

E, seja para provar a capacidade feminina, seja para sublimar a atração que sentia pelo pai, Silvina adota um comportamento viril, assumindo um papel quase masculino. Entretanto, ao invés de anular a paixão, essa atitude paradoxalmente desperta naquele um desejo ainda maior, numa sugestão do homossexualismo que trazia latente:

Para se defender dos seus direitos femininos, que implicavam o perigo de ceder, foi, pouco a pouco, adquirindo um interesse pelo travesti, tornando-se na virago que toda gente apreciava na sua ditadura doméstica. [...] Contudo, Eros tem uma mão que descobre e outra que encobre, como o próprio diabo. Esse travestimento de Silvina, que a fazia fumar, tratar de negócios e gostar de armas, tinha o seu lado inquietante. [...] Podia, em suma, revelar um ponto fraco em João Trindade, até aí negado expressamente pelo seu donjuanismo: a sua latente carga homossexual. ${ }^{9}$

Além de ser um dos mais fortes interditos da sociedade, o incesto entre Silvina e João é temperado por indícios de

\footnotetext{
${ }^{8}$ MONTEIRO, 1999, p. 34.

${ }^{9}$ BESSA-LUÍS, 1990, p. 169.
} 
homossexualismo, numa agravante do crime que se ensaia cometer. A dessacralização do patriarca, que se verifica em Eugénia e Silvina talvez de forma mais flagrante do que em qualquer outro romance da autora, conta ainda com outros elementos de transgressão, intensificando a ruptura da ordem vigente, como o assassinato de João Trindade, com a sugestão de parricídio que perpassa a obra. Assim, incesto, lesbianismo, homicídio e misoginia cruzam-se no romance, trazendo à tona tabus da sociedade ocidental cristã para questioná-los.

Se a afirmação do eu é feita à medida que o indivíduo vaise desvencilhando do vínculo com a matriz, sendo os complexos de Édipo e Electra as últimas tentativas frustradas de fusão com a origem, cabe ao ser a aceitação de sua incompletude, a ser resolvida na busca de outro objeto de desejo. No caso de Silvina, cuja referência paterna surge tardiamente - ela é perfilhada aos quinze anos, e só então conhece o pai-, o desejo edipiano não é simbólico, mas carnal, sendo a morte do pai a única forma de libertação desse desejo temporão, e, talvez por isso, insuperável. A primeira forma de sublimação encontrada pela personagem - relato detalhado das peripécias sexuais do pai, numa espécie de voyeurismo - não é suficiente para aplacarlhe a libido, sendo necessária a morte daquele para pôr fim a essa paixão despudoradamente correspondida.

Dulcinéia da Mata Monteiro, no já citado estudo Mulher: feminino plural, analisa as distinções entre os gêneros a partir, sobretudo, de suas manifestações psíquicas. Psicanalista junguiana, a autora pensa o paralelo possível entre a mitologia grega e a multidimensionalidade do arquétipo feminino. Ao estabelecer a pluralidade feminina, a autora afirma ser tal multiplicidade decorrente das diversas facetas manifestadas pela mulher, sendo cada uma correspondente a uma deusa da mitologia greco-latina. Assim, apesar de cada mulher trazer consigo todas as potencialidades - a mãe, a esposa, a amante, a guerreira - sua personalidade a identifica com uma deusa em 
particular, sem que nada a impeça de manifestar as características de outras deusas em alguns momentos de sua vida.

Ártemis encarna o aspecto da jovem donzela destinada à castidade, sendo ainda associada à caça e ao instinto. Por ser a deusa que mais se distancia dos papéis destinados à mulher, caracteriza-se pela não-sujeição a um homem e à sociedade circundante.

Fisalina, assim como tantas outras personagens femininas de Bessa-Luís, executa a subversão da ordem vigente. Seu desejo de transgredir assinala a diferença entre a personagem e os demais membros da aldeia habitada por ela, constituindo a sua marca pessoal. Com seu temperamento arrebatado, ela apresenta a voracidade e a obstinação que caracterizam a deusa caçadora: "[...] Ártemis desperta o espírito de conquista e de luta, de arriscar-se e de criar valores objetivos. Um ego tão pleno em si, que não necessita de parceiro para completar o seu circuito energético."10

Essa autossuficiência manifestada pelas mulheres-Ártemis, recorrentes em Agustina, faz delas mulheres geralmente solitárias, uma vez que não aceitam a submissão a um homem. É o caso, por exemplo, das irmãs Teixeira, d'O mosteiro, para quem o casamento é um risco.

A contestação surge através da negação da realidade opressora que cerca a mulher, fazendo-a subverter os valores vigentes. No romance citado, o clã feminino recusa a lei patriarcal, questionando a objetividade e o pragmatismo masculinos.

A virgindade - marca da deusa da castidade - aparece no romance como signo de liberdade, de não-sujeição, fazendo de Assunta e de Aurora exemplos da atuação de Ártemis. A força das mulheres-Ártemis acaba por determinar-lhes a solidão, pois outra característica dessa deusa é o desprezo pela fraqueza

${ }^{10}$ MONTEIRO, 1999, p. 125. 
alheia. Curiosamente, a Fisalina d'A mãe de um rio percebe que não ama o namorado ao vê-lo prostrado e implorando pelo seu amor.

Já o arquétipo de Atena representa a sabedoria, a reflexão, o espírito empreendedor. Mitologicamente, ela teria saído da cabeça de Zeus, o que explica o poder de discernir que lhe é atribuído. Sendo filha apenas do pai, é a deusa que mais se aproxima do viril. Várias são as personagens agustinianas que trazem a iniciativa e a racionalidade como características. Seria essa, por exemplo, a principal marca da Quina d'A sibila, que administra a propriedade com eficiência e conversa com os homens em pé de igualdade, recusando o casamento para não perder a independência.

A referência ao pensamento e ao modo de agir masculinos atua como crítica à sociedade falocrática, que cala a voz feminina baseada na valorização de características supostamente superiores e masculinas. Numa inversão de perspectivas, Agustina retrata os homens como irresponsáveis, enquanto ressalta a consciência feminina. Quina toma para si o encargo de administrar as terras da família por não haver nenhum homem capaz de fazê-lo. $\mathrm{N}^{\prime} A$ sibila, a virilidade da personagem manifesta-se de modo diretamente proporcional à inconsequência masculina. Em outras palavras, Quina possui, como Atena, as qualidades ditas masculinas que faltam aos irmãos e ao pai. $\mathrm{O}$ homem, aqui visto como elemento de desequilíbrio, ameaça a harmonia desse clã feminino.

Quina encarna a mulher-Atena e, através de suas características, ganha espaço entre os homens. Estrategicamente, transita por esferas acessíveis somente àqueles, colocando-se numa posição que lhe permite analisar a condição feminina. Fazendo-se respeitar pelos negociantes e lavradores, Quina lida fria e racionalmente com as situações, enquadrando-se no princípio da mulher-Atena. Com o propósito de não se comportar como as mulheres cujas atitudes abomina, Quina 
mostra-se contida em seus sentimentos, o que lhe confere um poder estratégico sobre os demais.

Preterida pela mãe, que nutria uma indiscutível preferência pela irmã, Quina ganha o pai como aliado, aproximando-se ainda mais da tipologia da deusa da sabedoria. Sua identificação com ele ainda na infância, aliada ao desprezo pelas atitudes mesquinhas a que certas mulheres têm de recorrer, gera em Quina uma recusa do comportamento feminino, ressaltando os aspectos viris de sua personalidade. Entretanto, o status que a personagem adquire está ligado à sua fama como adivinha. É por meio da intuição - marca tipicamente feminina - que Quina se torna conhecida. Contudo, os supostos dons divinatórios da personagem nada mais são do que uma considerável capacidade de observação. Quina recebe o título de Sibila graças à sua habilidade em observar e analisar, chegando a inferências que soavam aos simplórios como adivinhações. Paradoxalmente, é justamente o olhar racional que lhe vale o rótulo místico.

A partir de sua fama como sibila, Quina passa a ter prestígio e até mesmo influência sobre algumas pessoas. Entretanto, o preço a ser pago seria a renúncia ao amor de Adão, cuja admiração ela preferiu manter, ainda que para isso tivesse de negar o próprio sentimento. Ciente de que sua condição dependia de sua solidão, ela não hesitou em se afastar do homem a quem amava para se manter forte.

A recusa ao pedido de casamento confirma as qualidades de mulher-Atena em Quina. Tudo a que ela renuncia é compensado por outros aspectos, mais valorizados, o que acaba por identificá-la ainda mais com a essência racional da deusa.

A atitude para com Custódio, o filho adotivo, é outro aspecto que assinala a racionalidade de Quina. Apesar do amor desmedido que sente pelo rapaz, ela mantém a imparcialidade e, mesmo sofrendo, consegue ser fria e objetiva o bastante para não lhe deixar a herança. Consciente da frivolidade do rapaz a 
quem ama mais do que a todos, a protagonista opta por beneficiar a sobrinha, que promoverá a continuidade do nome, da linhagem feminina e da terra. Seu gesto, que choca o filho, na verdade traz a marca de Atena, que: "[...] está sob o domínio do arquétipo de Zeus. [...] Torna-se difícil distinguir entre virtude e tirania de julgamento na consciência de Atena."11

Em Eugénia e Silvina, esta última vale-se de uma postura viril como defesa diante da sociedade patriarcal, na qual a mulher é tolhida. Assim, enquanto o marido viaja, é ela quem cuida dos negócios. Torna-se pejorativamente conhecida como Silvino, num reflexo da sociedade que rotula de forma negativa a mulher independente.

A virilidade observada em Silvina toca em um ponto crucial, que envolve o travestismo e o mito da donzela guerreira: a necessidade de a mulher assumir e / ou incorporar características masculinas para ter acesso a coisas que, sendo mulher, lhe seriam negadas. Joana d'Arc e Diadorim espelham uma sociedade que nega oportunidades à mulher, e é sob o disfarce de um homem que certas mulheres conseguem provar o próprio valor.

Outro típico exemplo de mulher-Atena pode ser visto na Josefina d'O mosteiro, cujos hábitos e gostos são associados aos estereótipos ligados ao universo masculino. Além do desejo de poder apresentado pela personagem, sua habilidade no manuseio de armas dá à sua atitude certa virilidade, visto serem as armas dotadas de uma conotação fálica. Além disso, a personagem revolta-se diante do autoritarismo paterno, cujas ações parecem se limitar a inquirir e a ordenar. Dessa forma, a mulher-Atena, talvez por sua identificação com o masculino e pela sabedoria que a caracteriza, não admite a submissão.

${ }^{11}$ MONTEIRO, 1999, p. 123. 
Em contraste, a deusa Hera reflete a esposa instituída. Vendo no casamento o sentido de sua vida, põe em prática um projeto de vida a dois, no qual a parceria conduz à estabilidade e ao status. Abre mão da paixão em prol do prestígio e do respeito trazidos pelo matrimônio. Apesar da aparente submissão sugerida por tal figura, ela tem a sensação de ser a artífice do marido. Em Agustina, cujas personagens são marcadas por uma quase aversão ao homem, geralmente associado à ruína e à irresponsabilidade, dificilmente se encontra uma mulher-Hera. Entretanto, a Estina d'A sibila apresenta características que a aproximam do arquétipo de Hera, uma vez que aceita se casar com um déspota apenas para gozar dos privilégios de uma mulher casada no tocante à posse da terra. Não se trata aqui do casamento como meta de vida, mas de alguém cuja visão pragmática acerca do matrimônio faz com que perceba as vantagens ao invés de se deixar guiar pelo amor. Estina suporta com resignação os maus-tratos do marido, como se essa aceitação a enobrecesse. Sobre a essência de Hera, diz o estudo de Dulcinéa da Mata:

[...] É a esposa. [...] Ela não tem identidade fora do casamento, e, geralmente, nesta relação não há aprofundamento, pois ela não é criativa. [...] Se ele precisar de dinheiro, ela trabalhará para ele triunfar; se ele quiser se mudar ela facilmente aceitará. [...] Ela expressa a capacidade do compromisso político. [...] Quer ter poder igual ao do marido. ${ }^{12}$

Mesmo percebendo a frivolidade do pai e dos irmãos, Estina casa-se, e o fato de ser infeliz acentua a dissociação entre amor e casamento. Em uma sociedade que valoriza a mulher casada, ela faz da união uma conveniência, comportando-se como Hera diante dos caprichos de Zeus:

${ }^{12}$ MONTEIRO, 1999, p. 137-138. 
Apesar desta prevenção azeda contra todos os homens, esta antipatia que era reprovação [...], Estina casou. Foi um enlace de conveniência, não para ela, que aceitou o encargo duma casa mediana e dum marido hipocondríaco [...]. Temia que os irmãos, uma vez escarmentados de infortúnios e de preguiças vadias, viessem roer o naco de pão que lhes competia [...]. Casando, ela aumentava as possibilidades de um dia licitar sobre os bens, manter ainda aquele aconchego de campos ligados por carreiros brancos $[. ..] .^{13}$

As mulheres da ficção agustiniana geralmente são celibatárias, e as que se casam mostram o lado negativo do matrimônio, numa crítica à instituição, uma vez que a representação de mulheres que se tornam alvo da tirania dos maridos denuncia o despotismo que grassava na sociedade portuguesa de então. Noémia, a mais romântica das irmãs Teixeira, jamais pôde realizar as fantasias que acalentava, pois foi vítima do sadismo do marido, em nada parecido com o homem de seus sonhos, num destino não muito diferente do que o da mãe de Salvador, também n'O mosteiro. A personagem Maria Rosa padece nas mãos do marido, vivendo atormentada:

[...] Reconhecia que ele fora valente e abnegado, retirando solicitamente do seu espírito aquelas noites em que ele chegava ébrio de raiva e partia os móveis se o estorvavam. Que noites longas e quase chegadas ao crime ela vivera, tremendo, pregada à cama, as pernas geladas de medo, esperando que ele entrasse no quarto e imaginasse um insulto novo! Como obrigá-la a comer no chão a ceia que lhe servia a ele na mesa. As lágrimas desesperavam-no; aprendeu a suspendê-las. Os cabelos soltos tentavam-lhe as sevícias; amarrava-os e cobria-os com uma touca que não fosse galante, porque a galanteria, ele abominava-a. ${ }^{14}$

${ }^{13}$ BESSA-LUÍS, s.d., p. 53-54.

14 BESSA-LUÍS, s.d., p. 21. 
Assim, as mulheres-Hera em Agustina surgem em circunstâncias tendenciosas, servindo para justificar a ojeriza ao casamento manifesta pelas demais, e acentuando o cunho feminista que marca a produção da autora.

Deméter, a deusa da agricultura, tem como eixo de sua história o rapto da filha Perséfone por Hades, que a leva para seus domínios, as profundezas. Após procurar desesperadamente pela filha sem qualquer resultado, paralisa a natureza. Nada mais floresce ou frutifica até que Hades decide autorizar Perséfone a passar uma parte do ano com a mãe. Segundo a mitologia, as estações do ano seriam o resultado desse acordo, correspondendo à alegria da mãe que reencontra a filha, e à tristeza por sua partida. Em virtude disso, Deméter é também associada à maternidade e à nutrição. O plantio e a colheita, simbólicos ou literais, refletem as fases da geração de vida. Como mãe -biológica ou não -, Deméter é a deusa ligada aos ciclos da vida, ao recomeço, ao porvir. A ligação com a filha traduz ainda a projeção, a continuidade no futuro.

A mulher-Deméter pode ser vista em Agustina na permanência e na transmissão de certos valores e tradições pelas mulheres de um mesmo clã. $N^{\prime} A$ sibila, a viril Quina que tanto representa a mulher-Atena, apresenta uma face Deméter ao ver na sobrinha Germa a perspectiva de continuação no futuro, aludida por Monteiro. Curiosamente, essa visão nem sempre é harmoniosa, e a tensão decorrente desse olhar especular, em que uma enxerga na outra os próprios defeitos, é flagrante na relação entre Quina e Germa, marcada pela intolerância mútua. Surpreendentemente, é a semelhança - e não a diferença - que causa o confronto entre ambas.

A mulher-Deméter apresenta um lado sombrio, justamente em virtude dessa identificação com a filha, o que, em certos casos, estabelece uma rivalidade entre ambas. Quina e Germa são tão parecidas que caem na armadilha de Deméter. A relação de amor e ódio vivida pelas personagens faz parte da 
mulher-Deméter, como explica Monteiro, em função de uma relação especular em que uma se vê na outra.

A despeito das dificuldades de relacionamento, a identificação de Quina com a sobrinha é tanta que no fim, numa atitude que surpreende a todos, é Germa quem herda os bens da tia. Mais do que simples herdeira, ela é a sucessora de Quina inclusive no aspecto espiritual, como nos é sugerido metonimicamente pela rocking-chair ao final do romance.

A perspectiva de continuação em outra, que se torna uma espécie de desdobramento de si, marca também a relação entre Fisalina e a Mãe do rio, na obra homônima. A Mãe, fatigada da indiferença dos seres humanos, elege Fisalina, a única a ter personalidade, como a nova guardiã do rio.

Se a Mãe assemelha-se a Deméter, Fisalina cumpre uma trajetória semelhante à de Perséfone, pois mergulha nas profundezas para se conhecer. Além disso, a Mãe do rio evoca ainda outra propriedade da deusa do cereal, relacionada à fecundidade e à nutrição. Afinal, Deméter possui ainda o dom de ser a nutriz, aquela cujos cuidados permitem o crescimento - biológico e emocional - do indivíduo. Responsável pela provisão de alimentos, a Mãe era venerada na aldeia e sua presença associada aos mistérios de vida e morte. A mudança em relação à sua imagem, passando a ser ignorada pelos membros da aldeia, reflete a ascensão das religiões patriarcais. Deméter, por se aproximar do arquétipo da Grande Mãe das religiões pagãs, talvez tenha sido a mais atingida pela misoginia da lei do Pai. Note-se que a amargura da Mãe aparece diretamente ligada à perda de seu papel de protetora da aldeia, num distanciamento compartilhado inclusive pela terra, que se torna estéril e árida.

Como se percebe, a Mãe é uma mulher-Deméter a quem fora negado o direito à maternidade. Significativamente, uma das consequências do seu afastamento será a fome que passará a assolar a aldeia. 
Outra típica mulher-Deméter pode ser vista na Assunta d'O mosteiro, cuja preocupação com a fome alheia a faz repetir constantemente a pergunta "Não tereis fome?", como se os males do mundo cessassem à primeira colherada.

Sua obsessão traduz um dos arquétipos mais relacionados ao feminino: o seio materno. Problemas adquiridos durante a fase oral, segundo especialistas, marcam definitivamente o adulto, pois estão relacionados ao acalanto e ao alimento ligados ao colo. A atitude maternal de Deméter lembra-nos da eterna carência humana, e os atributos dessa deusa caracterizam-se pela doação.

Talvez por ser aquela que mais se aproxima desse arquétipo, Assunta é a única a conseguir um lugar na memória afetiva de Belche, para quem as tias constituíam um clã despótico e inatingível.

A simbologia de nutriz da mulher-Deméter é vista também na personagem-título d'A mãe de um rio. O tempo de fome do momento atual contrasta com o tempo da Mãe, cuja marca era a abundância.

Outra mulher de Agustina que apresenta uma face Deméter é a Aurora d'O mosteiro. Em uma situação que parece remeter à própria mitologia e ao simbolismo de Deméter, os campos se tornam estéreis e tudo seca quando de sua morte. Assim como no mito grego, a natureza parece interagir com a força feminina, e é significativo o fato de os pessegueiros, símbolos de primavera e de fecundidade, perderem a sua propriedade. As mulheres-Deméter mostram principalmente a intrínseca relação entre feminino e natureza, constituindo uma imagem recorrente na obra da autora.

Na galeria de personagens femininas agustinianas, há um grupo que chama a atenção pela capacidade de se transformar. Circunstâncias externas, como a rejeição, ou internas, como a evolução psíquica, aliam-se na metamorfose que se opera nessas mulheres. Em virtude do crescimento interior decorrente 
dessa metamorfose, identificá-las-emos com Perséfone, a filha de Deméter.

A deusa Perséfone simboliza a renovação, a dor e a separação. Tendo sido raptada por Hades e conduzida ao inferno, Coré - seu nome anterior - nunca mais será a mesma. A morte de uma parte de si e o conhecimento decorrente da descida transformam-na em Perséfone, conhecedora de si e do outro mundo. Ciente dos segredos das profundezas, ela encarna o arquétipo da transformação. Sofrimento, perda, desvinculação, e, sobretudo, renovação pertencem ao reino de Perséfone. O mergulho no mundo subterrâneo propicia à donzela o conhecimento necessário à sua evolução. Como nas trajetórias iniciáticas, muda de nome à medida que vão ocorrendo mudanças interiores, numa simbologia de sua transformação como indivíduo. O mito de Coré / Perséfone mostra-nos a jovem donzela que passa a Rainha das Profundezas, companheira de Hades.

N'O sermão do fogo, Amélia vive movida a desafios. Quando lugares e situações se tornam previsíveis, ela sente que é hora de partir e recomeçar. Sua necessidade de evolução sobrepõe-se a paixões pessoais, às quais ela renuncia, executando um movimento cíclico de perpétuos reinícios. A constante renovação por que Amélia passa assemelha-se a uma iniciação, na qual a mudança é tão intensa que ela sequer se reconhece ao olhar para trás.

Ainda mais intensamente do que em Amélia, consideramos a Fisalina d'A mãe de um rio como a mulherPerséfone por excelência, por vermos em sua trajetória a mais radical das metamorfoses. Apesar da insatisfação diante da vida, a personagem do início da narrativa preocupa-se em ser aceita pelos irmãos, e sofre por ser repelida. Após o encontro com a Mãe, contudo, aceita a missão dos dedos de ouro, e consegue devolver a vida à aldeia, ainda que isso acarrete a sua proscrição. É com o conhecimento, obtido nas profundezas das 
grutas habitadas pela Mãe, que ela constata a própria força. Desejosa de mudanças, ela é a única à altura para substituir a Mãe.

O fascínio pelo desconhecido constitui o requisito fundamental para a mudança. E, se a descida de Fisalina aos subterrâneos éliteral, por outro lado essa imagem é extremamente expressiva para retratar processos de evolução psíquica. A metamorfose que se verifica é metonimizada nos dedos de ouro, marca da Mãe, num prenúncio da substituição desta por Fisalina. Curiosamente, isso não a surpreende, quase como se ela já o esperasse: "Só mais tarde notou que as pontas dos dedos da mão direita se tinham mudado em oiro. Aquilo quase não a surpreendeu, mas procurou que ninguém visse tal deformidade." ${ }^{\prime 15}$

Após a mudança, diversas são as passagens que retratam Fisalina contemplando a água profunda, ${ }^{16}$ numa referência ao processo de autoconhecimento, numa perda da inocência que constitui a marca de Coré / Perséfone.

Outro aspecto visível na mulher-Perséfone refere-se à ambivalência, à dualidade de quem precisa viver ora no mundo da luz, com Deméter, ora no mundo das sombras, com Hades. É esse o conflito vivenciado por Fisalina, guardiã do segredo dos dedos de ouro, orgulhosa de possuí-los, e temerosa diante da reação da aldeia. A liberdade implica a exclusão, mas sua escolha fica explícita na súplica que dirige à Mãe, em que ela implora por liberdade, ainda que isso signifique a sua maldição.

A angústia da protagonista leva-a a escolher o seu caminho, e nele está a evolução psíquica obtida com o autoconhecimento e com a identificação com a Mãe. Prevendo a rejeição da aldeia, Fisalina esconde-se e se considera amaldiçoada. Seu temor tem fundamento, como se verifica ao final da narrativa: ao descobrir

${ }^{15}$ BESSA-LUÍS, 1981, p. 35.

${ }^{16}$ BESSA-LUÍS, 1981, p. 38. 
o segredo da moça, a aldeia une-se em sua maldade para apedrejá-la, fazendo com que ela fuja e se isole para sempre nas montanhas. Seu sacrifício, entretanto, não terá sido em vão, uma vez que a crueldade dos membros da aldeia é o que devolve a emoção aos habitantes do lugar.

Em sua ânsia de se libertar da rejeição e do isolamento, Fisalina tem acesso a um poder desconhecido. Ironicamente, é esse mesmo dom o que a incompatibiliza definitivamente com o lugarejo caracterizado pela apatia. Marca da mulher-Perséfone, o surgimento do poder da Mãe faz dela uma amaldiçoada, o que a isola ainda mais, uma vez que sua evolução parece incomodar aqueles que a rodeiam. A mulher-Perséfone personifica, na ficção agustiniana, a transformação vivenciada pela mulher, o que, em sociedades patriarcais, significa ser condenada a descer, periodicamente, aos infernos da existência.

Afrodite, deusa do amor e da beleza, é aquela que acende o fogo das paixões. Sendo a mais ligada aos prazeres do sexo, vivencia uma relação com o corpo que transcende os conceitos de culpa ou pecado.

A valorização da beleza estética e a relação com o corpo como objeto de fascínio são aspectos encontrados em várias mulheres de Agustina. Irradiando beleza e deslumbrando todos à sua volta, a Assunção d'O mosteiro encarna o arquétipo da mulher-Afrodite: "[...] E nesse momento apareceu Assunção, a rainha. Grande, opulenta, com um penteador curto a que chamava "matinée" e donde saíam os braços torneados, ela ocupou de repente todo o espaço."17

Dotada do carisma de Afrodite, ela rouba a atenção de todos ao seu redor. Recebe o epíteto de rainha, numa sugestão da majestade que emana de sua presença. Plena de sensualidade, a mulher-Afrodite entrega-se aos próprios desejos como forma

17 BESSA-LUÍS, 1980, p. 15. 
de diversão. Dionisíaca, obedece a estímulos sem se preocupar com conceitos morais.

A visão pouco romântica do sexo, tomado em seu aspecto terapêutico, desvincula-o do amor, propiciando um comportamento muito mais liberal. A vaidade, outra marca da mulher-Afrodite, leva algumas dessas mulheres a manterem um séquito de homens atrás de si, ainda que nada sintam por eles. Em sua postura epicurista, percebe-se uma busca irrefreada de prazer, traduzindo os sinais de Afrodite, que compartilha seu corpo de um modo quase ritualístico.

Eugénia Viseu, em Eugénia e Silvina, também possui o magnetismo e o charme da mulher-Afrodite, cativando, com seu carisma, todos aqueles que lhe cruzam o caminho.

Além de ser fascinante em virtude de sua beleza, Eugénia ainda almeja possuir um caráter digno, o que faz dela um mito em sua época. O fato de rejeitar todos os pretendentes que lhe aparecem valoriza-a ainda mais, além de prenunciar a rebeldia dessa mulher-Afrodite. É a transgressão, motivada pela forte sensualidade da mulher-Afrodite, o que a coloca em desarmonia com os valores patriarcais, sendo esse descompasso uma característica das mulheres que se encaixam em tal tipologia.

A ativação do arquétipo de Afrodite, responsável pela transgressão dos interditos da sociedade patriarcal, faz-se notar nas atitudes de diversas mulheres agustinianas, geralmente associando um forte impulso sexual ao temperamento impetuoso que as caracteriza. Em Eugénia e Silvina, esta última traz a sociedade nas mãos ao personificar as taras e desejos inconfessáveis.

Uma das formas de negação dos cânones patriarcais está na naturalidade com que tais mulheres encaram o sexo. Desprovidas de preconceitos, desmitificam um dos maiores tabus da sociedade, escandalizando-a. Quanto mais irreverentes, mais sedutoras se tornam, abalando a ordem e as convenções.

As mulheres-Afrodite, devido à sedução que exercem, surgem por vezes associadas a desgraças, sugerindo a fase 
trágica e desmedida da paixão. A desordem é a marca dessas mulheres, que têm o poder de arrasar tudo ao seu redor.

Num choque de valores, a afirmação de Afrodite implica a transgressão aos códigos vigentes, e é por isso que as culturas patriarcais a abafaram mais do que a qualquer outra deusa. Através da valorização dos arquétipos da Esposa e da Mãe, a face Amante da mulher fica cada vez mais silenciada.

O sentimento de inadequação da mulher-Afrodite em tempos patriarcais faz-se notar nas reflexões de algumas personagens, que abominam a escravidão decorrente do amor único. A amargura sentida por ela reflete a descaracterização de Afrodite nas sociedades patriarcais. Para que tais sociedades se mantivessem estáveis, era necessário refrear as atitudes femininas, em virtude da desestruturação que podiam causar.

As mulheres-Afrodite completam o painel das deusas cujos arquétipos sintetizam as formas femininas de estar no mundo. A despeito de suas diferenças intrínsecas, todas têm em comum uma espécie de transcendência que as conduz a um plano distinto do da objetividade e da racionalidade humanas. Livres do jugo patriarcal, habitantes da região fronteiriça entre o concreto e a abstração, as mulheres agustinianas realizam misticamente aquilo que lhes é proibido na sociedade falocrática. Mães, esposas, amantes, guerreiras, elas cristalizam arquétipos que remontam ao eterno feminino. Afrodite, Ártemis, Atena, Perséfone, Hera e Deméter aliam-se na difícil tarefa de levar a transgressão ao Olimpo. 


\section{Referências bibliográficas}

BESSA-LUÍS, Agustina. A mãe de um rio. Lisboa: Contexto, 1981.

BESSA-LUÍS, Agustina. A sibila. Lisboa: Guimarães Editores, [s.d.].

BESSA-LUÍS, Agustina. Eugénia e Silvina. Lisboa: Guimarães Editores, 1990.

BESSA-LUÍS, Agustina. O mosteiro. Lisboa: Guimarães Editores, 1980.

BESSA-LUÍS, Agustina. O sermão do fogo. Lisboa: Guimarães Editores, 1962.

KEHL, Maria Rita. A mínima diferença: masculino e feminino na cultura. Rio de Janeiro: Imago, 1996.

KONG-DUMAS, Catherine. Mistério e Realidade na Obra de Agustina Bessa-Luís. Colóquio/Letras, n.70, nov. 1982.

MAGALHÃES, Isabel Allegro de. O tempo das mulheres. Lisboa: Imprensa Nacional - Casa da Moeda, 1989.

MAGALHÃES, Isabel Allegro de. Eugénia e Silvina de Agustina Bessa-Luís: um romance policial? Colóquio Letras, n. 115-116, maiago. 1990.

MAGALHÃES, Isabel Allegro de. Os véus de Ártemis: alguns traços da ficção narrativa de autoria feminina. Colóquio Letras, n. 125-126, jul-dez.1992.

MONTEIRO, Dulcinéa da Mata Ribeiro. Mulher: feminino plural: mitologia, história e psicanálise. Rio de Janeiro: Rosa dos Tempos, 1999. 


\section{Resumo}

Agustina Bessa-Luís apresenta a figura feminina como temática recorrente em sua obra. Dotadas de um caráter universal e cósmico, as personagens femininas agustinianas realizam um questionamento acerca do papel da mulher no mundo.

Acreditando que a trajetória e a caracterização das personagens femininas em Bessa-Luís refletem uma proposta de redimensionamento dos valores canonizados da sociedade patriarcal, o presente artigo pretende estabelecer a representação da condição feminina na obra da autora.

\section{Résumé}

Agustina Bessa-Luís, fait de la femme la thématique la plus fréquente de son oeuvre. Doués d'un caractère universel et cosmique, ses personnages féminins mettent en question le rôle de la femme dans le monde.

Admettant que la trajectoire et la caractérisation de ces personnages renvoient, chez Bessa-Luís, à une nouvelle dimenstion des valeurs canoniques imposées par la société patriarcale, cette étude se propose de définir la condition féminine telle qu'elle se présente dans l'oeuvre de cet écrivain portugais. 